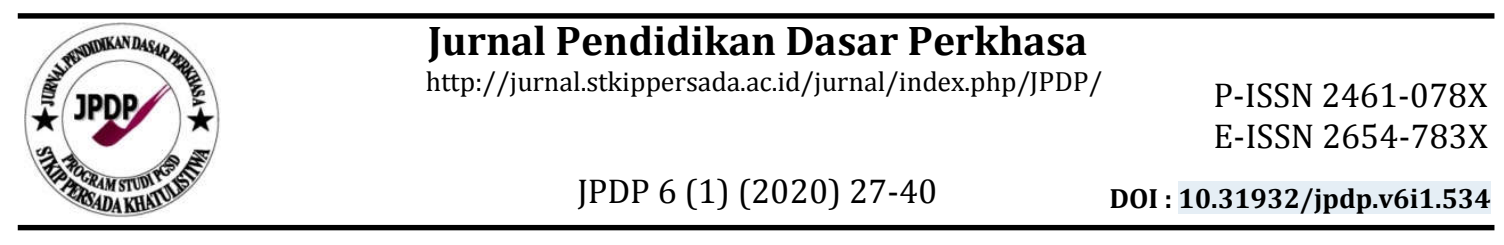

\title{
PENGARUH DIRECTED READING THINKING ACTIVITY TERHADAP KETERAMPILAN MEMBACA PEMAHAMAN SISWA KELAS V SEKOLAH DASAR
}

\author{
Satrianti*1 $^{\text {, Ide Said }}{ }^{2}$, Munirah ${ }^{3}$ \\ 1,2,3Program Studi PGSD, Univeristas Muhammadiyah Makassar
}

Diterima: 8 Nopember 2019. Dipublikasi: 8 April 2020.

\begin{abstract}
Reading is very important in order to understand the new information. This study aimed to determine the effect of the application of the learning model reading thingking activity directed toward students' reading comprehension skills class V SD 82 Pattene District of Marusu Maros. Quasi Experimenet type of research. The technique of collecting data using techniques of observation and tests. Data were analyzed using descriptive statistical techniques and analytical techniques infeersial. The results showed that there was significant difference to the learning outcomes Indonesian between experimental class model Thingking Directed Reading Activity in reading comprehension and grade control using conventional learning. Experimental class average value higher posttest results is 83,80 compared with the average value posttest results of the control that is 47.14. Where the value of $t$ Count equal to, 4.194> $t$ table 2.025 and 0.968 significant values $>0.05$, it can be concluded that $\mathrm{H} 0$ rejected and $\mathrm{H} 1$ accepted, which means the use of models DRTA against reading comprehension skills have a significant effect.
\end{abstract}

Keywords: A pretest, posttest, DRTA, significant

Abstrak. Membaca sangat penting agar dapat memahami informasi baru.Penelitian ini bertujuan untuk mengetahui pengaruh penerapan model pembelajaran directed reading thingking activity terhadap keterampilan membaca pemahaman siswa kelas V SD 82 Pattene Kecamatan Marusu Kabupaten Maros.Jenis penelitiannyaQuasi Experimenet.Teknik pengumpulan data menggunakan observasi dan teknik tes. Data dianalisis dengan teknik statistik deskriptif dan teknik analisis infeersial. Hasil penelitian menunjukkan bahwa terjadi perbedaan yang signifikan terhadap hasil belajar bahasa Indonesia antara kelas eksperimen yang menggunakan model Directed Reading Thingking Activity dalam membaca pemahaman dan kelas kontrol menggunakan pembelajaran konvensional. Kelas eksperimen nilai rata-rata hasil posttest lebih tinggi yaitu 83,80 dibandingkan dengan nilai rata-rata hasil posttest dari kontrol yaitu 47,14. Dimana nilai $t$ Hitung sebesar, 4,194>t tabel 2,025 dan nilai signifikan 0,968 > 0,05, maka dapat disimpulkan bahwa $\mathrm{H}_{0}$ ditolak dan $\mathrm{H}_{1}$ diterima yang artinya penggunaan model DRTA terhadap keterampilan membaca pemahaman berpengaruh signifikan.

Kata kunci: pretest, posttest, DRTA, signifikan 
Satrianti, I. Said, Munirah | JPDP 6 (1) April 2020, 27-40

Pendahuluan

Keterampilan berbahasa ada empat aspek, yaitu keterampilan menyimak, berbicara, membaca, dan menulis.Menyimak dan membaca merupakan aspek reseptif,sementara berbicara dan menulis merupakan aspek produkti.Dalam aktivitas berbicara, si pengirim pesan mengirimkan pesan dengan menggunakan bahasa lisan.Sementara, dalam menyimak si penerima pesan berupaya memberi makna terhadap bahasa lisan yang disampaikan si penyampainya.Dalam kegiatan menulis, si pengirim pesan mengirimkan pesan dengan menggunakan bahasa tulis. Di pihak lain, dalam membaca si penerima pesan berupaya memberi makna terhadap bahasa tulis yang disampaikan penulisnya.

Keterampilan berbahasa merupakan sesuatu yang penting untuk dikuasai setiap orang. Dalam suatu masyarakat, setiap orang saling berhubungan dengan orang lain dengan cara berkomunikasi. Tidak dapat dipungkiri bahwa keterampilan berbahasa adalah salah satu unsur penting yang menentukan kesuksesan mereka dalam berkomunikasi.
Keterampilan

berbahasa

bermanfaat dalam melakukan interaksi komunikasi dalam masyarakat. Banyak profesi dalam kehidupan bermasyarakat yang keberhasilannya, antara lain bergantung pada tingkat keterampilan berbahasa yang dimilikinya, misalnya profesi sebagai manajer, jaksa, pengacara, guru, penyiar, wartawan, dan lain-lain.

Permasalahan dalam pembelajaran bahasa Indonesia, yaitu adanyapandangan yang mengatakan bahwa: (1) orang yang rajin membaca dianggap sebagai orang kutu buku, (2) sikap yang menganggap bahwa banyak membaca tidak ada bedanya dengan sedikit membaca, tidak ada pengaruhnya dalam berbagai kegiatan hidup dan (3) budaya santai, orang dapat sukses dengan menghalalkan segala cara tanpa mau bersusah payah membaca dalam artian memperoleh pengetahuan. Hal tersebut menunjukkan bahwa membaca pemahaman dan budaya akan membaca masih rendah, terbukti dengan banyaknya anggapan yang menyudutkan kegiatan membaca. Inilah yang dapat mematahkan semangat belajar ke depan dan secara 
Satrianti, I. Said, Munirah | JPDP 6 (1) April 2020, 27-40

tidak langsung telah berakar dalam diri dan pikiran.

Keterampilan membaca adalah kemampuan yang diperoleh siswa selama mengikuti proses pembelajaran. Dengan siswa terampil membaca, siswa dapat melakukan proses produksi yang menghasilkan pengetahuan, pengalaman, dan sikapsikap baru. Menurut Farr (dalam Dalman, 2013:5) bahwa, reading is the heart of education yang artinya membaca merupakan jantung pendidikan. Dalam hal ini, orang yang sering membaca, pendidikannya akan maju dan ia akan memiliki wawasan yang luas. Tentu saja hasil membacanya itu akan menjadi skemata baginya.

Membaca pemhaman merupakan keterampilan membaca yang berada pada urutan yang lebih tinggi. Membaca pemahaman adalah membaca secara kognitif (Membaca utnuk memahami). Dalam membaca membaca pemhaman, pembaca dituntut mampu memhami isi bacaan. Oleh sebab itu, Setelah membaca teks, sipembaca dapat menyampaikan hasil pemhaman pembacaanya dengan cara membuat rangkuman isi bacaan dengan menggunakan bahasa sendiri dan menyampaikanya baik seecra lisan maupun tulisan

Menurut Russel G. Stauffer (dalam Munirah, 2017:129) Strategi Directed Reading Thinking Activity (DRTA) memfokuskan keterlibatan siswa dengan teks, karena siswa memprediksi dan membuktikannya ketika siswa membaca. Dalam pembelajaran membaca pemahaman, siswa dapat menemukan gagasan utama dalam teks. Dengan adanya prediksi dalam strategi Directed Reading Thinking Activity (DRTA) siswa secara otomatis mempertanyakan pertanyaan mereka sendiri yang merupakan bagian dari proses pemahaman suatu teks. Siswa akan cermat dan berpikir kritis dalam membaca sehingga siswa memahami teks bacaan.

Model pembelajaran Directed Reading-Thinking Activity sehingga ditemukan bahwa kemampuan membaca yang dimiliki oleh sebagian siswa masih tergolong rendah. Berdasarkan data hasil ulangan harian, terdapat sebagian siswa yang dinyatakan mengulang/remedial dalam tes membaca. Hal ini disebabkan oleh beberapa faktor yang muncul dari berbagai aspek, baik 
Satrianti, I. Said, Munirah | JPDP 6 (1) April 2020, 27-40

faktor eksternal maupun faktor internal. Faktor-faktor tersebut bukan hanya terjadi di salah satu sekolah saja, namun pada umumnya di banyak sekolah juga dihadapi banyak kendala dalam penyampaian pengajaran Bahasa Indonesia. Penyampaian pembelajaran Bahasa Indonesia yang dilakukan oleh guru pada umumnya masih menggunakan metode konvensional yang lebih mementingkan pencapaian materi, sementara peserta didik tidak lebih hanya sebagai pendengar. Senada Widya Arta Pujana ( 2014) ejurnal volume 2 nomor 1, meneliti dengan judul Pengaruh Metode Pembelajaran DRTA terhadap Keterampilan Membaca Pemahaman Bahasa Indonesia Siswa Kelas IV. Hasil penelitian menunjukan bahwa terdapat perbedaan pemahaman konsep yang signifikan antara kelompok siswa yang belajar dengan menggunakan metode pembelajaran SQ3R dan kelompok siswa yang belajar dengan menggunakan model pembelajaran konvensional dalam pembelajaran bahasa Indonesia (thitung $=6,29 ; p<0,05$ ). Ini berarti bahwa metode pembelajaran SQ3R berpengaruh lebih baik terhadap keterampilan membaca pemahaman bahasa Indonesia dibandingkan dengan metode pembelajaran kovensional.

Adapun rumusan masalah pada penelitian ini adalah sebagai berikut:

1. Bagaimana keterampilan membaca pemahaman siswa sebelum diterapkan model DRTA (Directed Reading Thinking Activity)?

2. Bagaimana keterampilan membaca pemahaman siswa setelah diterapkan model DRTA (Directed Reading Thinking Activity)?

3. Apakah model pembelajaran DRTA (Directed Reading Thinking Activity) berpengaruh signifikan terhadap keterampilan membaca pemahaman siswa kelas V SD 82 Pattene Kecamatan Marusu Kabupaten Maros?

\section{Metode}

Penelitian yang digunakan adalah penelitian kuantitatif. Model penelitian ini adalah eksperimen semu (quasi experiment), dengan menggunakan dua kelompok subyek penelitian yang hampir sama (homogen). Penelitian ini dilakukan di 
Satrianti, I. Said, Munirah | JPDP 6 (1) April 2020, 27-40

SDN 82 Pattene yang terletak di jl

Pattene Desa Tamappadduae,

Kecamatan Marusu, Kabupaten Maros,

Provinsi Sulawesi Selatan.. Penelitian ini dilakukan pada awal bulan November sampai akhir Januari 2019.

Populasi dari penelitian ini adalah seruluh siswa kelas V SD Negeri 82 Pattene Kecamatan Marusu Kabupaten Maros yang terdiri atas 2 kelas yaitu kelas $\mathrm{Va}$ dan $\mathrm{Vb}$ dengan jumlah keseluruhan siswa adalah 66 siswa. Sampel penelitian sebanyak 60 siswa.Teknik pengambilan sampel yang digunakan yaitu purposive sampling.Pengambilan sampel yang digunakan menentukan karakteristik untuk menjawab masalah penelitian. Karakteristik yang dimaksud di antaranya jenis kelamin, dan prestasi siswa berdasarkan nilai rapor. Teknik pengumpulan data yang digunakan dalan penelititianini adalah dengan menggunakan observasi dan teknik tes.
Teknik analisis deskriptif dalam penelitian ini bertujuan untuk memberikan gambaran penerapan metode Directeed Reading-Thinking Activity (DRTA) dan membaca pemahaman siswa dalam pembelajaran bahasa Indonesia setelah penerapan metode Directeed Reading-Thinking Activity (DRTA) pada siswa kelas V SD Negeri 82 Pattene Kecamatan Marusu Kabupaten Maros. Deskripsi tentang pelaksanaan pembelajaran melalui penerapan metode Directeed ReadingThinking Activity (DRTA) dijelaskan berdasarkan tahap-tahap pembelajaran metode Directeed Reading-Thinking Activity (DRTA).

Dalam analisis ini peneliti menetapkan tingkat keterampilan siswa dalam membaca pemahahaman sesuai dengan prosedur yang dicanangkan oleh Depdikbud (2003) seperti Tabel 1.

Tabel 1. Kategori Minat Baca Siswa

\begin{tabular}{ccc}
\hline No. & Skor & Kategori \\
\hline 1. & $75-100$ & Baik \\
2. & $65-74$ & Cukup Baik \\
3. & $35-64$ & Kurang Baik \\
4. & $0-34$ & Kurang
\end{tabular}

Untuk mengetahui ada tidaknya terhadap membaca pemahaman siswa pengaruh penerapan metode DRTA V SD 82 Pattene Kecamatan Marusu dalam pembelajaran bahasa Indonesia Kabupaten Maros, maka digunakan 
Satrianti, I. Said, Munirah | JPDP 6 (1) April 2020, 27-40

analisis uji- beda/ t-test (Analisis data dengan menggunakan software SPSS 22.0 for windows). Sebelum melakukan analisis hipotesis maka dilakukan uji normalitas dan uji homogenitas yang bertujuan untuk melihat data tersebut telah berdistribusi normal dan homogen.

\section{Hasil dan Pembahasan}

Hasil

Data yang diperoleh Peneliti terlebih dahulu menguji instrumen penelitian tiap variabel dengan tujuan untuk memperoleh tingkat validitas dan tingkat reabilitas instrumen penelitian yang digunakan, pengujian ini terlampir pada lampiran kemudian peneliti melakukan analisis data untuk mengetahui hasil penelitian dan menjawab rumusan masalah dengan menggunakan software SPSS 20,0 for windows untuk menjawab tiap-tiap rumusan masalah yang dapat kita lihat sebagai berikut.

Tabel 2. Rekapitulasi Distribusi data Kelas Eksperimen dan Kelas Kontrol Siswa SD 82 Patene Kecamatan Marusu Kabupaten Maros

\begin{tabular}{lcccc}
\hline \multirow{2}{*}{\multicolumn{1}{c}{ Data }} & \multicolumn{2}{c}{ Kelas Eksperimen } & \multicolumn{2}{c}{ Kelas Kontrol } \\
\cline { 2 - 5 } & Pretest & Posttest & Pretest & Posttest \\
\hline Nilai tertinggi & 86 & 100 & 66 & 93 \\
Nilai terendah & 40 & 75 & 26 & 60 \\
Mean & 63.23 & 83.80 & 47.14 & 75.97 \\
Median & 60 & 80 & 40 & 73 \\
Modus & 53 & 80 & 33 & 73 \\
Standar Deviasi & 12.46 & 9.52 & 14.46 & 8.66 \\
\hline
\end{tabular}

Berdasarkan tabel 2., ukuran rata-rata (mean) 83.80, median pemusatan dan penyebaran data hasil pretest untuk kelas eksperimen yaitu: sebesar 80 , modus sebesar 80 dan standar deviasi 9.52.

skor terbesar 86 dan skor terkecil 40,

\section{a. Uji normalitas data}

rata-rata (mean) sebesar 63.23, 1) Uji normalitas data pretest median sebesar 60 modus sebesar 53 Hasil perhitungan uji normalitas dan standar deviasi sebesar 12.46 . untuk pretes kelas eksperimen dan Sedangkan data hasil posttest skor kelas kontrol dilihat pada tabel 3. tertinggi 100 dan skor terendah 75, 
Satrianti, I. Said, Munirah | JPDP 6 (1) April 2020, 27-40

Tabel 3. Uji Normalitas Data (Pretest)

One-Sample Kolmogorov-Smirnov Test

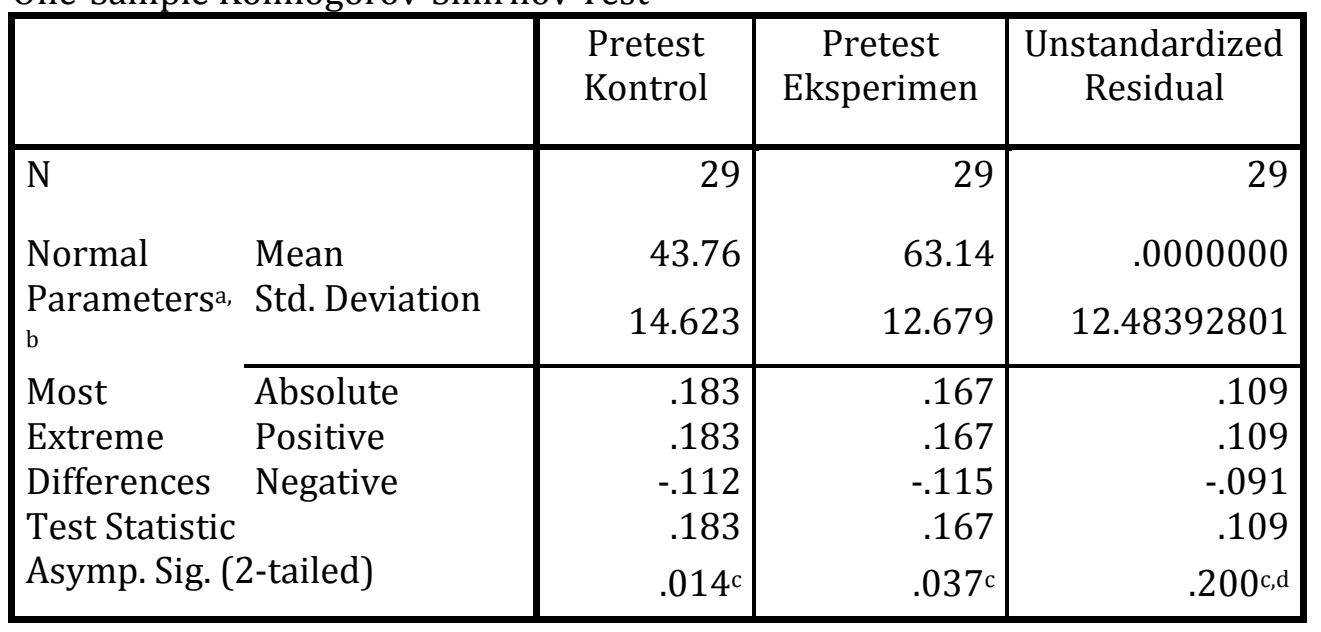

Hasil uji normalitas di atas kelompok sama-sama berdistribusi menunjukkan hasil uji One-Sample normal berdasarkan hasil tabel OneKolmograv-Smirnov Test. Nilai p value Sample Kolmograv-Smirnov Test.

(Sig.) pada kelompok control yaitu 0,14 dan pada kelompok eksperimen yaitu 0,37. Maka, berdasarkan tabel normalitas di atas menunjukkan kedua kelompok $>0,05$, maka kedua

\section{2) Uji normalitas posstest}

Hasil perhitungan uji normalitas untuk pretes kelas eksperimen dan kelas kontrol dilihat pada tabel berikut.

\section{Tabel 4 Uji Normalitas Data (Posttest)}

\begin{tabular}{|ll|r|r|r|}
\hline & \multicolumn{1}{|c|}{$\begin{array}{c}\text { Postest } \\
\text { Kontrol }\end{array}$} & $\begin{array}{c}\text { Postest } \\
\text { Eksperimen }\end{array}$ & $\begin{array}{c}\text { Unstandardized } \\
\text { Residual }\end{array}$ \\
\hline $\mathrm{N}$ & 30 & 30 & 30 \\
Normal & Mean & 75.97 & 83.80 & .0000000 \\
Paramete & Std. & 9.223 & 12.626 & 12.62527593 \\
rsa,b & Deviation & .174 & .152 & .148 \\
Most & Absolute & .164 & .152 & .148 \\
Extreme & Positive & -.174 & -.148 & -.145 \\
Differenc & Negative & .174 & .152 & .148 \\
es & & $.021^{\mathrm{c}}$ & $.076^{\mathrm{c}}$ & $.090^{\mathrm{c}}$ \\
Test Statistic & & & \\
Asymp. Sig. (2-tailed) & & & \\
\hline
\end{tabular}

b. Uji Homogenitas

\section{1) Uji Homegenitas Pretest}

Uji homogenitas dilakukan untuk mengetahui varians dari kedua kelompok data, yaitu nilai pretest 
Satrianti, I. Said, Munirah | JPDP 6 (1) April 2020, 27-40

kelompok control dengan kelompok dapat dilihat pada tabel berikut. eksperimen. Hasil uji homogenitas

Tabel 5. Uji Homogenitas Data (Pretest)

Test of Homogeneity of Variances

\begin{tabular}{|c|c|c|c|}
\hline $\begin{array}{c}\text { Levene } \\
\text { Statistic }\end{array}$ & df1 & df2 & Sig. \\
\hline 1.690 & 6 & 22 & .171 \\
\hline
\end{tabular}

Dari tabel di atas dapat dilihat bahwa nilai p value (sig.) adalah 0,171 dan $>0,05$ sehingga dapat disimpulkan bahwa kedua kelompok data hasil belajar siswa yang berasal dari kelompok kontrol dan kelompok eksperimen bersifat homogen.
2) Uji homogenitas kelas posttest

Uji homogenitas dilakukan untuk mengetahui varians dari kedua kelompok data, yaitu nilai posttest kelompok control dengan kelompok eksperimen. Hasil uji homogenitas dapat dilihat pada tabel berikut:

Tabel 6. Uji Homogenitas Data posttest

Postest Eksperimen

\begin{tabular}{|c|c|c|c|}
\hline Levene Statistic & df1 & df2 & Sig. \\
\hline 1.192 & 4 & 23 & .341 \\
\hline
\end{tabular}

Dari tabel di atas dapat dilihat bahwa nilai p value (sig.) adalah 0,341 $>0,05$ sehingga dapat disimpulkan bahwa kedua kelompok data hasil belajar siswa yang berasal dari kelompok kontrol dan kelompok eksperimen bersifat homogen.

\section{c. Uji T (Uji Hipotesis )}

Uji $\mathrm{T}$ digunakan untuk melihat perbedaan hasil belajar antara kelas eksperimen dan kelas kontrol. Dimana pada kelas eksperimen menerapkan model pembelajaran DRTA pada keterammpilan membaca pemahaman, sedangkan pada kelas kontrol hanya menggunakan pendekatan konvensional. Hasil uji T dianalisis menggunakan IBM SPSS statistic 22. Uji T disajikan pada tabel dibawah ini. 
Satrianti, I. Said, Munirah | JPDP 6 (1) April 2020, 27-40

Tabel 7. Uji T Independent Samples T-test (Posttest)

\begin{tabular}{|l|r|r|r|r|r|}
\hline \multirow{2}{*}{ Model } & \multicolumn{2}{|c|}{$\begin{array}{c}\text { Unstandardized } \\
\text { Coefficients }\end{array}$} & $\begin{array}{c}\text { Standardized } \\
\text { Coefficients }\end{array}$ & & \\
\cline { 2 - 5 } & \multicolumn{1}{|c|}{$\mathrm{B}$} & $\begin{array}{c}\text { Std. } \\
\text { Error }\end{array}$ & \multicolumn{1}{|c|}{ Beta } & \multicolumn{1}{c|}{$\mathrm{T}$} & \multicolumn{1}{c|}{ Sig. } \\
\hline 1 (Constant) & 83.006 & 19.791 & & .040 & .000 \\
Postest Kontrol & .010 & .259 & .008 & 4.194 & .968 \\
\hline
\end{tabular}

Berdasarkan tabel 7, terlihat hasil nilai $\mathrm{t}$ hitung adalah 4,194 dengan $t$ table 2,025 dan nilai signifikan (Sig) 0,968 > 0,05, Maka, dapat disimpulkan bahwa terdapat perbedaan yang signifikan untuk pembelajaran membaca pemahaman dengan menggunakan metode pembelajaran model DRTA dengan pembelajaran konvensional.

\section{Pembahasan}

Berdasarkan hasil analisis deskriptif data tes awal (pretest) dan tes akhir (posttest) keterampilan menulis siswa kelas $\mathrm{V}$ pada kelas eksperimen menggunakan model DRTA dan kelas kontrol menggunakan model konvensional menunjukkan bahwa nilai siswa yang berada pada kelas eksperimen dengan menggunakan model DRTA lebih tinggi. Hal ini ditunjukkan bahwa materi pelajaran yang disampaikan kepada siswa oleh guru tersampaikan dengan baik dan dapat dipahami oleh siswa.Pemahaman siswa terhadap materi yang diajarkan disebabkan oleh penggunaan model DRTA yang digunakan pada kelas eksperimen. Model Directed Reading-Thingking Activity dikembangkan oleh Staufer (dalam Munirah, 2017:129). DRTA adalah model yang memandu siswa melalui membaca,membuat prediksi, membaca ulang, dan menginformasikan atau menyesuaikan kembali prediksi. Model ini membantu siswa dalam pengembangan pemahaman bacaan.

Hal ini dapat dilihat dari data tentang keterampilan membaca pemahaman siswa kelas V SD Pattene kelas kontrol pretes diperoleh data yaitu: skor tertinggi 66 dan skor terendah 25, rata-rata (mean) sebesar 47,14, median sebesar 49, modus 
Satrianti, I. Said, Munirah | JPDP 6 (1) April 2020, 27-40

sebesar 33 dan standar deviasi sebesar 14,46 sedangkan data yang diperoleh pada pretest kelas eksperimen yaitu: skor tertinggi 86 dan skor terendah 40, rata-rata (mean) 63,23, median 60, modus 53 dan standar deviasi 12,46. Berdasrkan data yang diperoleh dapat disimpulkan bahwa keterampilan membaca pemahaman siswa siswa kelas V SD Pattene sebelum diterapakan model pembelajaran DRTA termaksud dalam kategori kurang.

Data keterampilan membaca pemahaman siswa kelas V SD 82 Pattene setelah diterapkan model DRTA untuk postest kelas kontrol diperoleh data yaitu: skor tertinggi 93 dan skor terendah 60, rata-rata (mean) 75,97, median 73, modus 73 dan standar deviasi 8,66 sedangkan data hasil postest kelas eksperimen diperoleh data yaitu: skor tertinggi 100 dan skor terendah 75, rata-rata (mean)83,80, median 80 modus 80 dan standar deviasi 9.52. Berdasarkan nilai rata-rata pada kelas eksperimen dan kelas kontrol dapat disimpulkan bahwa dengan menerapkan model directed reading thinking activity dalam keterampilan membaca pemahaman siswa dapat meningkatkan hasil belajar siswa. Hal itu dapat dibuktikan dari nila rata-rata siswa kelas kontrol 75,97 sedangkan nilai rata-rata kelas eksperimen postest 83,80 .

Pada Uji T, Terlihat hasil nilai $\mathrm{t}$ hitung adalah 0.40 dengan $t$ table 0,33 dan nilai signifikan (Sig) 0,968 > 0,05, Maka, dapat disimpulkan bahwa terdapat perbedaan yang signifikan untuk pembelajaran membaca pemahaman dengan menggunakan metode pembelajaran model DRTA dengan pembelajaran konvensional.

Untuk pengamatan kegiatan pembelajaran konvensional sebagai kelas kontrol yang diajarkan dengan metode pembelajaran konvensional, siswa tidak semangat untuk belajar, kurang aktif, banyak yang merasa bosan akhirnya berbicara bahkan ada yang bermain dan bergurau sesama teman. Dari penjelasan diatas dapat ditarik kesimpulan bahwa dengan menerapkan model pembelajaran DRTA lebih efektif berhasil mengingkatkan hasil belajar siswa dibandingkan menggunakan pembelajaran dengan pendekatan konvensional. Sedangkan untuk kegitan pembelajaran membaca 
Satrianti, I. Said, Munirah | JPDP 6 (1) April 2020, 27-40

pemahaman dengan menerapkan menunjukkan (1) terdapat perbedaan model pembelajaran DRTA siswa secara signifikan hasil belajar antara semangat untuk belajar, aktif, siswa yang mengikuti strategi DRTA sehingga pembelajaran berjalan dengan siswa yang mengikuti strategi dengan baik dan hasil belajar pembelajaran konvensional $(\mathrm{F}=$ membaca pemahaman sangat efektif.

\section{Model Directed Reading-}

Thingking Activity dikembangkan oleh Staufer (dalam Munirah, 2017:129). DRTA adalah model yang memandu siswa melalui membaca, membuat prediksi, membaca ulang, dan menginformasikan atau menyesuaikan kembali prediksi. Model ini membantu siswa dalam pengembangan pemahaman bacaan.

Model pembelajaran DRTA yang telah dikemukan diatas juga terbukti saat peneliti melakukan penelitian bahwa model DRTA dapat mempermudah siswa dalam memahami isi bacaan dan dapat mengembangkan pemahamannya terhadap bacaan.

Menurut Putri Anggreni ( 2013) pada penelitian relevan dengan judul Pengaruh Strategi Directed Reading Thinking Activity (DRTA) Terhadap Sikap Sosial dan Kemampuan Membaca Pemahaman Bahasa Inggris Siswa Kelas Viii SMP Dharma Wiweka Denpasar. Hasil penelitian 28,956, p <0,05). (2) Terdapat perbedaan secara signifikan sikap sosial antara siswa yang mengikuti strategi DRTA dengan siswa yang mengikuti pembelajaran Konvensional $(\mathrm{F}=27,580, \mathrm{p}<0,05) \cdot \operatorname{dan}(3)$ Terdapat perbedaan yang signifikan membaca pemahaman bahasa Inggris dan sikap sosial secara simultan antara siswa yang mengikuti strategi DRTA dengan siswa yang mengikuti strategi pembelajaran Konvensional (F untuk Pillai's Trace, Wilks' Lamda, Hotelling's Trace danRoy's Largest Root memiliki signifikansi lebih kecil dari 0,05).

Hasil penelitian di atas memiliki persamaan dengan penelitian yang dilakukan oleh peneliti, Penerapan model pembelajaran DRTA dapat meningkatkan hasil belajar membaca pemahaman siswa. hasil penelitian menunjukan bahwa Dimana kelas eksperimen nilai rata-rata hasil posttest lebih tinggi yaitu 83,80 dibandingkan dengan nilai rata-rata hasil posttest dari kontrol yaitu 75,97. 
Satrianti, I. Said, Munirah | JPDP 6 (1) April 2020, 27-40

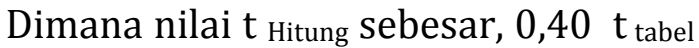
0,33 dan nilai signifikan $0,968>0,05$, maka dapat disimpulkan bahwa $\mathrm{H}_{0}$ diterima dan $\mathrm{H}_{1}$ ditolak yang artinya penggunaan model DRTA terhadap keterampilan membaca pemahaman berpengaruh signifikan. Perbedaan peneliti menerapkan model DRTA dalam membaca pemahaman pada pembelajaran Bahasa Indonesia sedangkan Putri Anggreni menerapkan model DRTA terhadap sikap social dan kemampuan membaca pemahaman Bahasa Inggris dan perbedaanya juga dapat dilihat pada hasil penelitian yang berbeda. Dapat disimpulkan bahwa model pembelajaran DRTA sangat membantu siswa dalam proses belajar membaca pemahaman karena dengan menerapkan model DRTA siswa dapat lebih mudah memahami isi bacaan yang mereka baca dan megembangkan pengetahuan yang mereka peroleh.

\section{Simpulan}

Berdasarkan hasil penelitian dan pembahasan maka, dapat disimpulkan bahwa keterampilan membaca pemahaman siswa kelas V SD 82 Pattene Kecamatan Marusu Kabupaten Maros sebelum diterapkan model pembelajaran DRTA dikategorikan sedang karena tidak mengalami peningkatan hasil belajar yang signifikan dengan nilai rata-rata 63.23.

Keterampilan membaca pemahaman siswa kelas V SD 82 Pattene Kecamatan Marusu Kabupaten Maros setelah diterapkan model pembelajaran DRTA dikategorikan tinggi karena mengalami peningkatan hasil belajar yang signifikan dengan nilai rata-rata 83.80. Hal ini dapat dilihat dari hasil belajar siswa yang memiliki perbedaan yang siginfikan antara hasil belajar kelas eksperimen dan kelas control.

Model pembelajaran DRTA terhadap keterampilan membaca pemhaman pada siswa kelas V SD 82 Pattene Kecamatan Marusu Kabupaten Maros berpengaruh signifikan. Hal ini dapat dilihat dari hasil belajar siswa yang memiliki perbedaan yang signifikan antara hasil belajar kelas eksperimen dengan kelas control. Dimana nilai $t$ Hitung sebesar, $4,194>t$ tabel 2,025 dan nilai signifikan $0,968>0,05$, maka dapat disimpulkan bahwa $\mathrm{H}_{0}$ ditolak dan $\mathrm{H}_{1}$ diterima yang artinya penggunaan model DRTA 
Satrianti, I. Said, Munirah | JPDP 6 (1) April 2020, 27-40

terhadap keterampilan membaca pemhaman berpengaruh signifikan.

\section{Daftar Pustaka}

Anggreni, P. (2013). Pengaruh Strategi Directed Reading Thinking Activity (DRTA) terhadap Sikap Sosial dan Kemampuan Membaca Pemahaman Bahasa Inggris Siswa Kelas Viii SMP Dharma Wiweka Denpasar. PENDASI : Jurnal Pendidikan Dasar Indonesia 3(1).

Dalman. (2016). Keterampilan Menulis. Jakarta: Interpratama Mandiiri.

Dalman. (2017). Keterampilan Membaca. Jakarta: PT Raja Grafindo Persada.

Departemen Agama RI. 2007. AlQur'an dan Terjemahanya AlJumanatul 'Ali Seuntai Mutiara Yang Maha Luhur. Bandung : JArt.

Depdiknas. (2003). Undang-Undang RI No. 23. tentang Sistem Pendidikan Nasioanal.

Doyin dan Wagiran. (2009). Bahasa Indonesia Pengantar Penulisan Karya Ilmiah. Semarang: UNNES Press.
Margono. (2004). Metodologi Penelitian Pendidikan. Jakarta : PT Rineka Cipta. Mayuni, S. (2014). Pengaruh Model Pembelajaran Kooperatif Tipe Group Investigation terhadap Keterampilan Membaca Pemahaman Siswa Kelas IV Sd di Gugus Iii Kecamatan Kubutambahan. MIMBAR PGSD Undiksaha, 2(1).

Munirah. (2017). Teori Belajar dan Model Pembelajaran.Makassar : CV Media Sembilan-Sembilan.

Munirah. (2018). Evaluasi Keterampilan Berbahasa Indonesia. Makassar: Berkah Utami.

Nurgiyantoro, B. (2013). Penilaian Pembelajaran Bahasa Berbasis Kompotensi. Yogyakarta :Badan Persatuan Percetakan Fakultas

Ekonomi Unevirsitas Negeri Jakarta.

Nurjaya, G. (2018). Keterampilan Berbahasa Indonesia.Depok : PT Raja Grafindo Persada.

Pujana, W. A. (2014). Pengaruh Metode Pembelajaran SQ3R terhadap Keterampilan Membaca Pemahaman Bahasa Indonesia Siswa Kelas IV di SD 
Satrianti, I. Said, Munirah | JPDP 6 (1) April 2020, 27-40

Gugus VI Kecamatan Buleleng. Somadayo, S. (2011). Strategi dan MIMBAR PGSD Undiksha, 2(1).

Teknik Pembelajaran Membaca.

Ratnaningsih E. (2012). Evektivitas Yogyakarta: Graha Ilmu.

Metode Drill dan Resitasi dalam Meningkatkan Membaca

Pemahaman dan Keterampilan

Siswa Terhadap Hukum Bacaan

Qalqalahdan RO' SMP Negeri

Subang.Jurnal Pendidikan Agama Islam-Talim, 10(1).

Rikke, K. (2012). Kemampuan

Membaca Pemahaman Siswa

Kelas Xii Sma di Surabaya. Jurnal

Bahasa dan Sastra Indonsia,1(1).

Samiruddin dkk. (2016). Hubungan

Kemampuan Membaca

Pemahaman dengan

Kemampuan Menulis Teks Berita

pada Siswa Kelas Xi IPA Sma

Gunung Sari Makassar.Jurnal

Keguruan dan Ilmu

Pendidikan.3(1).

Sugiyono. (2016). Metode Penelitian

Kuantitatif, Kualitatif, dan $R \& D$.

Bandung: Alfabeta.

Sulistiantini, N. M.P. (2013). Pengaruh

Circ terhadap Keterampilan

Membaca Pemahaman Siswa

Kelas V Gugus Xi Kec. Buleleng

Tahun 2013. MIMBAR PGSD

Undiksha, 2(1).

Susanto, A. (2013). Teori Belajar dan

Pembelajaran di Sekolah Dasar.

Jakarta: Kencan Prenda Media

Group.

Sutari, I. dkk. (1997). Dasar-dasar

Kemampuan Menulis.

Bandung:FPBS IKIP Bandung.

Tarigan, H.G. (2015). Keterampilan

Berbahasa Indonesia.Depok : PT

Raja Grafindo Persada. 